\title{
A Cascaded Dual Buck Half-Bridge Inverter for Efficient Power Flow Control in Grid
}

\author{
S. Saravana Kiruthiga ${ }^{1}$, S. Rajasekaran ${ }^{2}$ \\ ${ }^{I} P G$ scholar, ME Power Electronics and Drives \\ ${ }^{2}$ Associate Professor, EEE Department \\ ${ }^{1,2}$ Einstein College of Engineering, Tirunelveli, Tamil Nadu, India
}

\begin{abstract}
This paper presents a single phase 7-level half bridge cascade dual buck multilevel grid-tied inverter with both active and reactive power flow control in a wide range under two types of renewable energy. The power flow is controlled by varying the switching pulse of the power semiconductor device used in the half bridge cascade dual buck multilevel grid-tie inverter. The multicarrier sinusoidal pulse width modulation $(S P W M)$ is used by which the power angle can be varied, by changing the switching pulse. By varying the power angle, the voltage and current at the grid side is changed. Active and Reactive power consumed or injected by each unit is depending on the shift angle between the current and modulated voltage in the each single unit of cascade dual buck inverter. Thus by varying the power angle, the power flow can be controlled effectively. The Total Harmonic Distortion (THD) is reduced, when compared with the 11-level cascade H-bridge grid-tie inverter. This is proved by using FFT analysis in MATLAB SIMULINK. The simulation is carried out for both type I and type II system in MATLAB SIMULINK. The experimental results have proved the effectiveness of the designed grid-tie control for both type I and type II system.
\end{abstract}

Keywords: half bridge cascade dual buck multilevel grid-tie inverter, renewable energy, multicarrier sinusoidal pulse width modulation, total harmonic distortion

\section{INTRODUCTION}

Distributed generation systems with grid-tie control are recent research topics with various circuit topologies and control method proposed. The industry demand for higher power equipment and controlled ac drives are usually connected to the medium-voltage network. Presently, it is hard to connect a single power semiconductor switch directly to medium voltage grids. For this reasons, a new family of multilevel inverters has emerged for working with high voltage level.

The cascade dual-buck half-bridge inverter inherits all the merits of cascade H-bridge inverter. Compared to cascade H-bridge inverter, it has several advantages. Most important of all, it eliminates the possibility of shoot-through problems, which is the major failure of traditional voltage source inverters. It does not need dead time, which fully utilizes the pulse width modulated (PWM) voltage and transfers total desired energy to the load. In addition, the cascade dual-buck inverter has the advantage to use high-voltage power MOSFETs without the complexity of soft-switching assisting circuits to improve the system efficiency.

In terms of cascade inverter grid-tie control, renewable energy sources can be classified into two types. A fuel-cell power conditioning system (PCS) is a Type I system and photovoltaic or wind PCS is a Type II system.

Traditional, LC filter is used for an inverter power supply. A grid-interconnected inverter, however, has some unique requirements that an LC may not be sufficient. A PWM converter with higher switching frequency will result in smaller LC filter size. However, switching frequency is generally limited in high power applications. As an alternative solution, LCL filter is more attractive. The main advantage of using LCL filter is that it gives better attenuation and provides inductive output at grid interconnection point to prevent inrush current.

This paper first presents a single phase 7-level half bridge cascade dual buck multilevel grid-tied inverter with both active and reactive power flow control in two types of renewable energy. Second, to reduce the total harmonic distortion compared to 11-level cascade H-bridge grid-tie inverter.

\section{TOPOLOGY AND SYSTEM BLOCK DIAGRAM}

The proposed cascade dual buck inverter has two basic forms, cascaded dual buck half bridge inverter and cascade dual buck full bridge inverter. This paper will focus on the power control of the cascade dual buck half-bridge inverter in grid, to demonstrate the feasibility and advantages.

The proposed inverter in this paper features a different series connection concept, the cascading, which has separate dc power supplies for each cell, and is extended to $\mathrm{N}$ unit connection, and shares the same LCL filter components. 
Fig.1 shows the topology of the cascade dual buck half-bridge inverter connected with LCL filter and the output is synchronized with the grid. The cascade dual buck half-bridge inverter consists of $\mathrm{N}$ units of single dual buck half bridge inverter. Each unit is framed of two power MOSFETs and two fast recovery diodes. Each unit has two output ports, iP and $\mathrm{iN}(\mathrm{i}=1,2, \ldots \ldots, \mathrm{N})$. In cascade topology, port $1 \mathrm{P}$ and $\mathrm{NN}$ are used as the output ports and the $\mathrm{iN}$ port of the $\mathrm{i}^{\text {th }}$ unit is connected with the $(\mathrm{i}+1) \mathrm{P}$ port of the $(\mathrm{i}+1)^{\text {th }}$ unit.

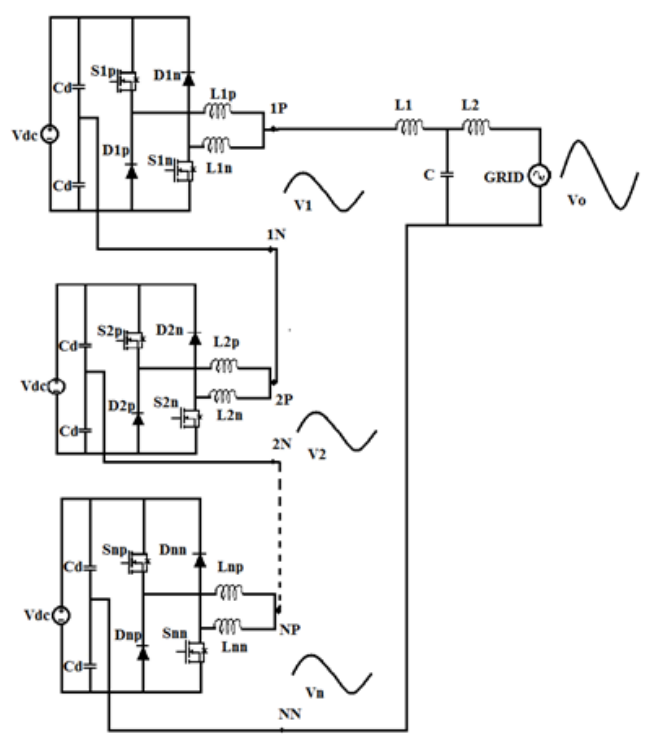

Fig.1. Topology of Cascade Dual Buck Half-Bridge Inverter

Sin and Din are a working pair, and operate at the negative half-cycle of output current. Sip and Dip are another working pair, and operate at the positive half-cycle of output current. The single unit operation of cascaded dual buck half-bridge inverter is shown in Fig.2. For the cascade dual buck inverter, if phase-shift control is not adopted, we can switch all the units exactly the same way as single-unit inverter. This means the PWMs for Sip and Sin are the same. However, this will bring the zero-crossing distortion problem of single-unit dual buck inverters into the cascade topology. In addition, without phase-shift control, the cascade topology loses the benefits of increased equivalent switching frequency and reduced output current ripple.

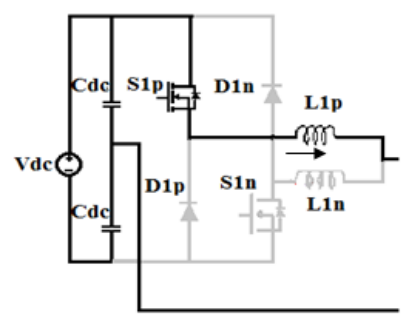

(a)

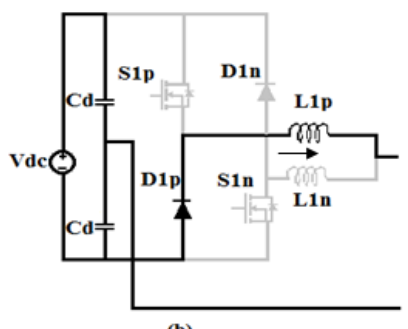

(b)

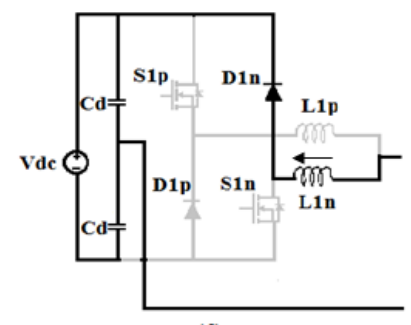

(d)

Fig. 2 Operation modes of single-unit dual buck half-bridge inverter.(a) Positive current, $S 1 \mathrm{p}$ turned ON. (b) Positive current, $D 1 \mathrm{p}$ free-wheeling. (c) Negative current, $S 1 \mathrm{n}$ turned ON. (d) Negative current, $D 1 \mathrm{n}$ freewheeling.

\subsection{TYPE I SYSTEM}

The overall block diagram of type I grid-tie power control system is shown in Fig 3. A fuel cell is a device that converts the chemical energy from a fuel into electricity through a chemical reaction with oxygen or 
another oxidizing agent. Hydrogen is the most common fuel, but hydrocarbons such as natural gas and alcohols like methanol are sometimes used. Fuel cells are different from batteries in that they require a constant source of fuel and oxygen/air to sustain the chemical reaction; however, fuel cells can produce electricity continually for as long as these inputs are supplied. The dc electrical supply by the fuel cell which is then converted into ac supply by the half bridge cascade dual buck multilevel inverter which is then given to the LCL filter and then synchronized with the grid.

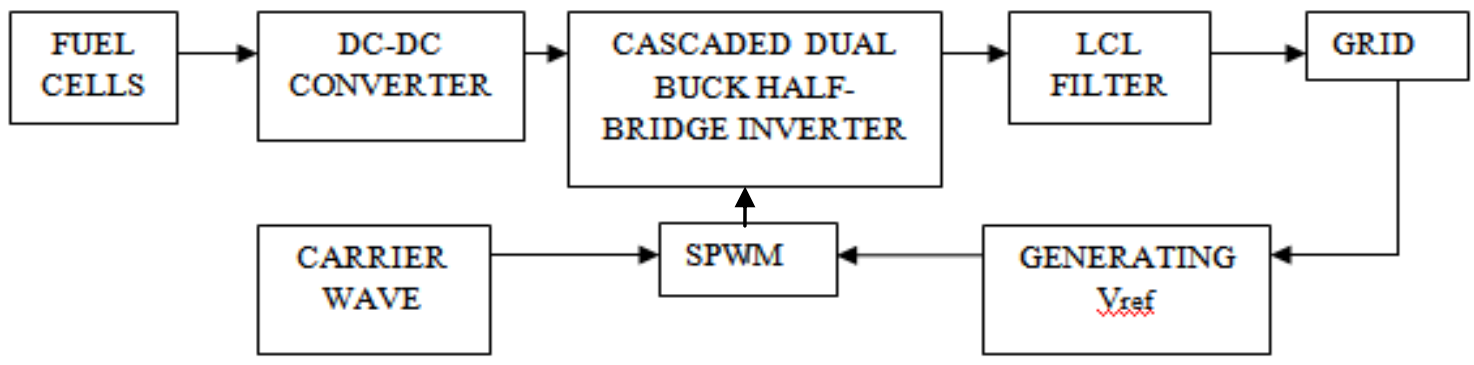

Fig. 3 Block diagram of Type I grid-tie PCS.

\subsection{TYPE II SYSTEM}

The overall block diagram of the half bridge Cascaded dual buck multilevel inverter employing renewable photovoltaic dc source is shown in Fig 4. The solar energy from the sun is converted into dc electrical supply by the solar PV module which is then converted into ac supply by the half bridge cascaded dual buck multilevel dc link inverter which is then given to the load.

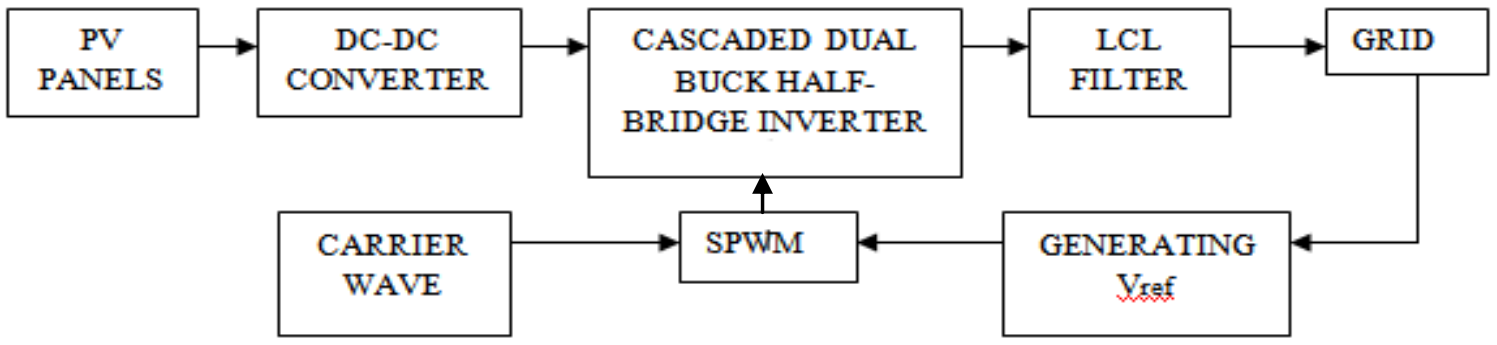

Fig. 4 Block diagram of Type II grid-tie PCS.

III. GRID-TIE CONTROL FOR TYPE I SYSTEM

Fig. 3 shows the Type I system structure. Each fuel cell energy source is connected to the individual unit of cascade dual-buck inverter through the dc-dc converter. The dc-dc converter boost ratio can be greatly reduced or the dc-dc converter is even not required if the cascade units are enough to generate the output grid voltage.

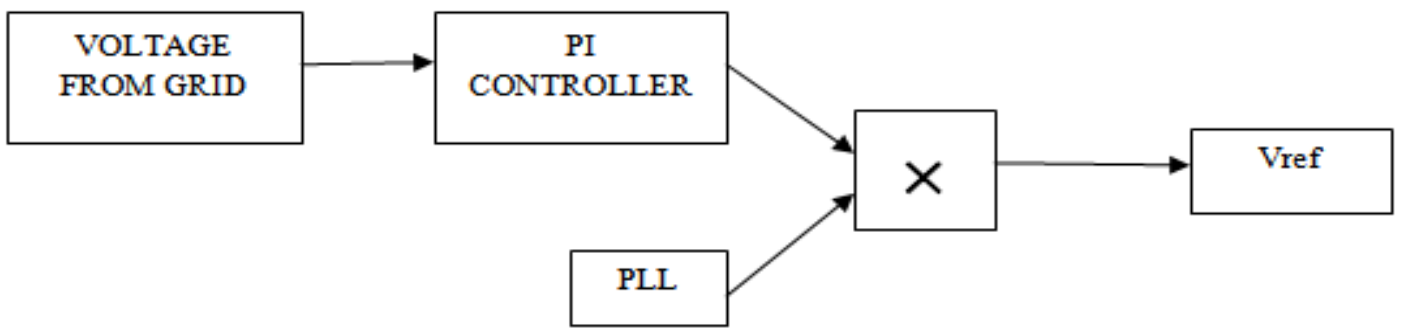

Fig.5. Block diagram for generating Vref

The output of the grid can be used to generate the Vref with is used for generating pulse for switching cascade half bridge dual buck inverter. The RMS value of the grid voltage is product with (1/230), since it is single phase. Then the error value is made steady using PI controller. To synchronize the grid with the inverter, the result is product with the discrete virtual PLL of $50 \mathrm{~Hz}$. The resulting output is used as Vref . This Vref is used in multicarrier sinusoidal pulse width modulation method to generate pulse for switching semiconductor device of half bridge cascade dual buck inverter. The Fig. 5 shows the block diagram of generating Vref. 


\section{GRID-TIE CONTROL FOR TYPE II SYSTEM}

Fig. 4 shows the Type II system structure. Each PV or wind energy source is connected to individual unit of cascade dual buck inverter through the dc-dc converter or ac-dc converter. Similar to cascade H-bridge inverter, when used in PV grid-tie applications, in order to eliminate the leakage current caused by PV panel stray capacitance, the dc-dc converter needs to be designed with high-frequency transformer to solve the problem. If the front stage $\mathrm{dc}-\mathrm{dc}$ converter is nonisolated, some measures can be done with the cascade inverter unit to cut the path of leakage current.

\section{EXPERIMENTAL RESULTS}

A cascade dual-buck inverter grid-tie system has been designed to verify the effectiveness of the control for both Type I and Type II systems. The passive component selected are $\mathrm{L} 1=0.1 \mathrm{H}, \mathrm{C}=.001 \mathrm{~F}$ and $\mathrm{L}_{2}=.00047 \mathrm{H}$.

\subsection{Type I System}

The voltage and current waveform of the grid connected half bridge cascade dual buck inverter for type I system is shown below in the Fig 6.

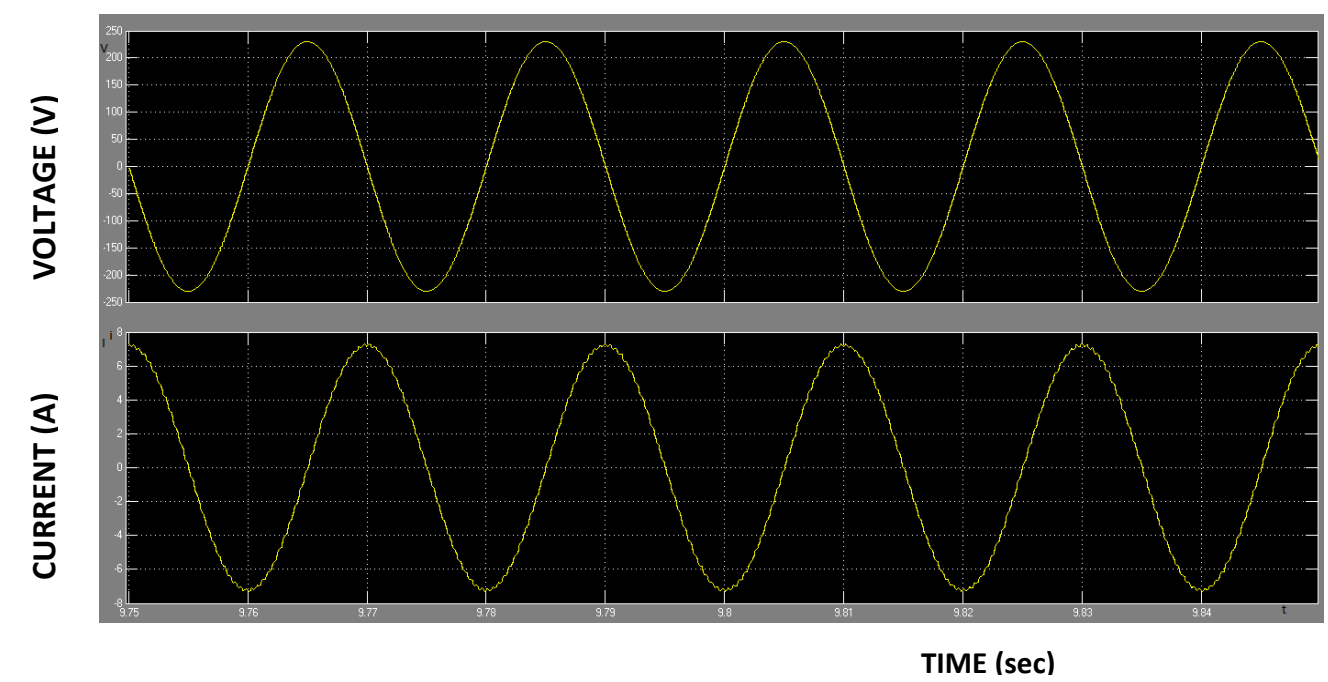

Fig 6.Voltage and Current waveform of the grid connected Half Bridge Cascade Dual Buck inverter for type I

system

Each fuel cell stack has generation capacity of $48 \mathrm{v}$ dc. It consists of three fuel cell stack with seven levels cascaded multilevel inverter. Each fuel cell stack has generation capacity of $48 \mathrm{v}$ dc. This voltage is fed to boost converter, which is used to convert from $48 \mathrm{v}$ dc to $96 \mathrm{v}$ dc. The output of dual buck inverter is around $230 \mathrm{v}$ ac. This output ac is synchronized with ac grid and supplied to the local loads. Here the carrier based pulse width modulation technique with sinusoidal reference signal is used.

The total harmonic distortion (THD) of the gird current in type I system is shown in the Fig 7.

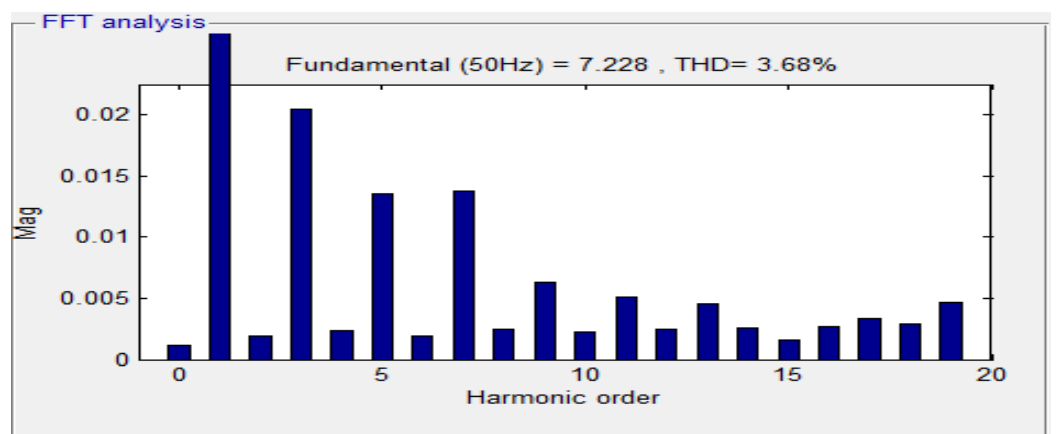

Fig 7 THD of the grid current for type I system

\subsection{Type II System}

The voltage and current waveform of the grid connected half bridge cascade dual buck inverter for Type II is shown below in the Fig 8 . 


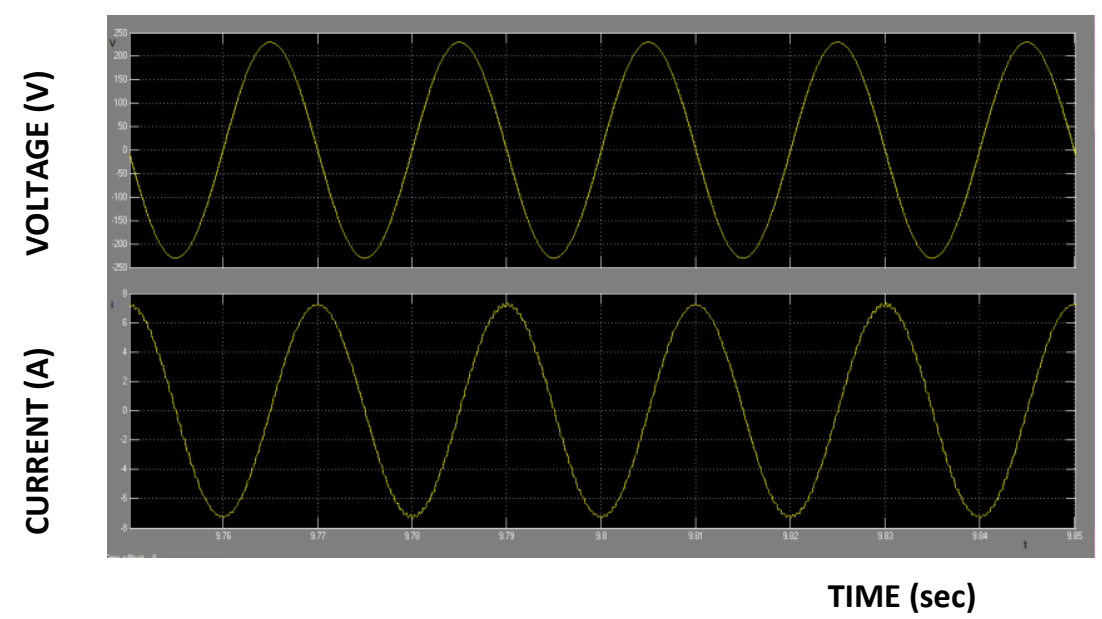

Fig 8 Voltage and Current waveform of the grid connected Half Bridge Cascade Dual Buck inverter for type II system

Each panel consists of four cells. Each cell has generation capacity of 5 volts dc and it is connected in series. Each panel generates $20 \mathrm{v}$ dc. It is connected in series. The voltage generated by the panels is $60 \mathrm{v}$ dc and it is converted into $120 \mathrm{v}$ dc by using boost converter. Then it will convert into ac with magnitude of $230 \mathrm{v}$ ac by using dual buck cascaded $\mathrm{H}$ bridge converter. This ac is synchronized with ac grid. The power is controlled using half bridge cascade dual buck inverter. The output of dual buck inverter is around $230 \mathrm{v}$ ac and the current is $7 \mathrm{~A}$.

The total harmonic distortion (THD) of the gird current in type I system is shown in the Fig 9.

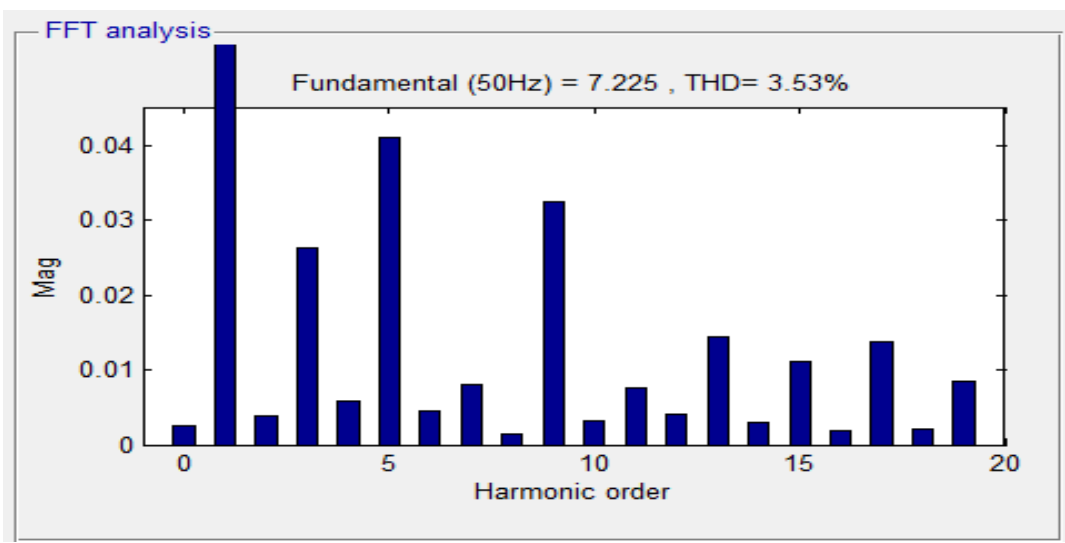

Fig 9 THD of the grid current for type II system

\subsection{THD Minimization}

The standard allows a limit of 5\% for the current total harmonic distortion (THD) with individual limits of $4 \%$ for each odd harmonic from 3 rd to 9 th and $2 \%$ for $11^{\text {th }}$ to 15 th. In order to see the effectiveness of the control method, the measurement of current harmonics was conducted and the bar chart is illustrated in Fig. 7 and 9, which indicates the compliance with the IEEE 929 standard. The measured grid current THD was 3.68\% for type I system and $3.53 \%$ for type II system.

Table I Comparison Of 11-Level Cascade H-Bridge Grid-Tie Inverter With 7-Level Cascade Half Bridge Dual Buck Grid-Tie Inverter

\begin{tabular}{|l|l|l|l|}
\hline Parameter & $\begin{array}{l}\text { 11-level cascade H bridge } \\
\text { inverter interfaced with solar } \\
\text { panel }\end{array}$ & $\begin{array}{l}\text { 7-level half bridge cascade dual } \\
\text { buck inverter for type I system }\end{array}$ & $\begin{array}{l}\text { 7-level half bridge cascade } \\
\text { dual buck inverter for type II } \\
\text { system }\end{array}$ \\
\hline THD & $7.8 \%$ & $3.68 \%$ & $3.53 \%$ \\
\hline $\begin{array}{l}\text { Switching } \\
\text { Device }\end{array}$ & 12 & 6 & 6 \\
\hline
\end{tabular}

\subsection{Power Angle Calculation}

TABLE II shows the different response of power to different types of loads. The output will get differs for different loads such as pure resistive, reactive load, resistive-capacitor load and resistive inductor load. 
Table II Response Of Power To Different Types Of Loads

\begin{tabular}{|l|l|l|l|}
\hline S.NO. & TYPE OF LOAD & PHASE ANGLE & POWER FACTOR \\
\hline 1 & Pure resistive load & Zero phase angle & Unity power factor \\
\hline 2 & Reactive load & 90 phase angle & Power factor nearly zero \\
\hline 3 & RC load & Current leads voltage & Leading power factor \\
\hline 4 & RL load & Current lags voltage & Lagging power factor \\
\hline
\end{tabular}

1) TYPE I:

$\mathrm{P}=\mathrm{V} * \mathrm{I} * \operatorname{COS} \delta$

$117.3=230 * 7 * \operatorname{COS} \delta$

$\operatorname{COS} \delta=117.3 /(230 * 7)$

$\delta=\operatorname{COS}^{-1}(117.3 /(230 * 7))$

$=85.82$

2) TYPE II:

$\mathrm{P}=\mathrm{V} * \mathrm{I} * \operatorname{COS} \delta$

$119.6=230 * 7 * \operatorname{COS} \delta$

$\operatorname{COS} \delta=119.6 /(230 * 7)$

$\delta=\operatorname{COS}^{-1}(119.6 /(230 * 7))=85.74$

\section{VI. conclusion}

A new type of cascade dual buck half-bridge inverters is used for controlling active and reactive power in both type I and type II system. Cascade dual-buck half-bridge inverters are based on single-unit dual-buck half-bridge inverters. Compared to traditional cascade inverters, they have enhanced system reliability. They can achieve lower switching losses with the help of using power MOSFETs. In this paper, the power flow is controlled using half bridge cascade dual buck inverter. Thus the power can be controlled by varying the switching pulse. By varying the switching pulse, the power angle get change and according to change in power angle, the voltage and current get varied. Thus the active and reactive power flow is controlled. The THD level is reduced compared to the 11-level cascade $\mathrm{H}$ bridge inverter. The number of switching devices used in 7-level cascade H-bridge inverter is reduced.

\section{REFERENCES}

[1] Chen C.L., Liu C., Lai J.-S., Sun P. W., Cascade Dual Buck Inverter With Phase-Shift Control, IEEE Transactions on Power Electronics, vol. 27, no. 4. 2012.

[2] Gopakumar K., Malinowski M., Rodriguez J., P'erez M.A., A Survey On Cascaded Multilevel Inverters, IEEE Transactions on Industrial Electronics, vol. 57, no. 7, pp. 2196-2206. 2010.

[3] Filho F., Tolbert L.M., Yue C. , 11-Level Cascaded H-Bridge Grid-Tied Inverter Interface with Solar Panels, in Proceedings of IEEE, pp. 968-972. 2010.

[4] Chen C.-L., Lai J.-S., Lee Y.-S., Martin D., Wang Y. , Design Of Parallel Inverters For Smooth Mode Transfer Microgrid Applications, IEEE Transactions on Power Electronics, vol. 25, no. 1, pp. 6-15. 2010.

[5] Caluisi C., Cecati C., Piccolo A., Siano P., Sindona A., Multilevel Inverters And Fuzzy Logic For Fuel Cells Power Conditioning And Control, in Proceedings of IEEE, pp. 2739-2744. 2010.

[6] Biel D., Guinjoan F., Meza C., Negroni J. J., Energy-Balance And Sliding Mode Control Strategies Of A Cascade H-Bridge Multilevel Converter For Grid-Connected PV Systems, in Proceedings of IEEE, pp. 1155-1160. 2010.

[7] Correa P., Pacas M., Rodriguez J., Villanueva E., Control Of A Single phase Cascaded H-Bridge Multilevel Inverter For GridConnected Photovoltaic Systems, IEEE Transactions on Industrial Electronics, vol. 56, no. 11, pp. 4399-4406. 2009.

[8] Chen C.-L., Lai J.-S., Park S.-Y., A Wide-Range Active And Reactive Power Flow Controller For A Solid Oxide Fuel Cell Power Conditioning System, IEEE Transactions on Power Electronics, vol. 23, no. 6, pp. 2703-2709. 2008.

[9] Akagi H., Asakura J., Inoue S., Maharjan L., A Transformerless Battery Energy Storage System Based On A Multilevel Cascade PWM Converter, in Proceedings of IEEE , pp. 4798-4804. 2008.

[10] Carrasco J. M., Dominguez E., Franquelo L. G., Galvan E., Leon J. I., Sanchez J. A., Vazquez S., Controller Design For A SinglePhase Two-Cell Multilevel Cascade H-Bridge Converter, in Proceedings of IEEE, pp. 2342-2347. 2008.

[11] Blaabjerg F., Liserre M., Teodorescu R., Timbus A. V., Overview Of Control And Grid Synchronization For Distributed Power Generation Systems, IEEE Transactions on Industrial Electronics, vol. 53, no. 5, pp. 1398-1409. 2006.

[12] Cho S. E., Ise T., Kang F. S., Kim C. U., Park S. J., Multilevel PWM Inverters Suitable For The Use Of Stand-Alone Photovoltaic Power Systems, in Proceedings of IEEE, pp. 906-915. 2005.

[13] Blaabjerg F., Hansen S., Liserre M., Design And Control Of An LCL Filter-Based Three-Phase Active Rectifier, in Proceedings of IEEE, pp. 1281-1291. 2005.

[14] Blaabjerg F., Borup U., Liserre M., Teodorescu R. , A New Control Structure For Grid-Connected LCL PV Inverters With Zero Steady-State Error And Selective Harmonic Compensation, in Proceedings of IEEE , pp. 580-586. 2004.

[15] Sinha G., Ye Z. H., Yuan X. M., Wang T. C., Output Filter Design For A Grid-Interconnected Three-Phase Inverter, in Proceedings of IEEE, pp. 779-782. 2003. 